\title{
IMPACT OF NATURAL GROWTH STIMULANTS SUPPLEMENTED DIETS ON PERFORMANCE, CARCASS CHARACTERSTICS AND FEASIBILITY OF FINISHING CULLED FEMALE BUFFALOES
}

\author{
Safaa S.A. Khalil ${ }^{1}$ and M.H. Abdel Gawad ${ }^{2}$ \\ 1- Animal Production Institute, Agricultural Research Center, Dokki, Egypt \\ 2- Department of Animal Production, Faculty of Agriculture, Cairo University, \\ Giza, Egypt
}

\section{SUMMARY}

Twenty one culled female buffaloes with initial average weight of $435 \mathrm{Kg}$ and 40.4 mo average age were assigned into three equal groups. The study aimed to investigate the response of culled female buffaloes to two different natural growth stimulants throughout finishing period that lasted for 90 days. Treatments were; control (no stimulant supplementation), $10 \mathrm{~g} / \mathrm{h} / \mathrm{d}$ of More yeast and CenMose were added the concentrate diet of groups two and three, respectively. All the experimental groups were fed on concentrate feed mixture as a basal diet at $70 \%$, the rest receiived clover hay and rice straw. By the end of the study, digestion trial was carried out to measure feeding value and also three animals were slaughtered for carcass characteristics evaluation. Results obtained indicated that growth stimulants supplementation non-significantly improved nutrients digestibility, feeding value, feed conversion, average daily gain and carcass traits, especially with CenMose supplemented diet. Average daily gain, $\mathrm{Kg} / \mathrm{h}$ was $0.98,1.06$ and 1.2, respectively. Meat cut quantitiesy were increased in female buffaloes fed on CenMose supplemented diet. Generally, external and internal offals were not affected by either More yeast or CenMose supplements. Economic efficiency linearly and nonsignificantly increased by supplementation. It could be implied that supplementation of growth stimulants to culled female buffaloes finishing diets improves digestion pattern, daily weight gain, carcass traits, meat quality, and was economically feasible, referring to promising potential after being fed for long time as lactating animal.

Keywords: female buffalo, finishing, growth stimulants, performance, and carcass characteristics

\section{INTRODUCTION}

In Egypt, relatively high percentage of female buffaloes $(\sim 25-30 \%)$ is culled routinely due to different infertility problems (Khalil, 2000 and Eid et al., 2003). Such high percentage of culled females is considered as an important source of beef production. Growth promoters were widely used to enhance meat production. However, most of these agents are harmful to the consumers. This consumer's concern over the safety of chemical promoters has led to emphasis on using yeast

Issued by The Egyptian Society of Animal Production 
cultures as feed additives. Yeast culture in ruminant diets may integrate with rumen metabolism and result in an increase in the number of bacteria, especially celluolytic bacteria, microbial fermentation rates, the protein turnover of the microbes, the hydrogen ion exchange and the metabolism of carbohydrates (Williams, 1988). Live yeast culture supplements have been shown to improve weight gain and efficiency of feed utilization (Fallon and Harte, 1987; Hughes, 1988; McLeod et al., 1990; Edwards, 1991). Addition of yeast culture to ruminant diet may be more common in dairy cattle diets than beef cattle or growing steers. To our knowledge, using yeast cultures in culled female buffalo diets for meat production has not been investigated. So, supplementation of yeast culture and polysaccharides with other minerals and vitamins mix to culled female buffalo diets to improve performance, digestion, meat quantity and quality through finishing period were the main objective of this investigation.

\section{MATERIALS AND METHODS}

This investigation has been carried out in Mehallet Moussa Research Station, Buffalo Breeding Research Division, Animal production Research Institute, Agriculture Research Center, Ministry of Agriculture.

\section{Animals and feeding}

Twenty one culled female buffaloes were assigned into three similar groups for 90 days finishing period in a factorial design. The initial averages of live body weight and age were $429 \pm 43.76 \mathrm{Kg}$ and $40.1 \mathrm{mo}, 431 \pm 45.55 \mathrm{Kg}$ and $40.4 \mathrm{mo}$ and $445 \pm 38.46 \mathrm{Kg}$ and 40.6 mo for group one; control group (no growth stimulants supplementation) and group two (More yeast supplemented diet) and group three (CenMose supplemented diet), respectively. All animals were kept individually in semi-open sheds. Concentrate feed mixture (CFM), Egyptian clover hay and rice straw were fed in restricted diet regimen to fulfill nutrients requirement for $1.1 \mathrm{Kg}$ daily gain (Ranjhan, 1999). The concentrate diet was fed twice a day, while, clover hay and rice straw were given once. All treated animals were given $10 \mathrm{~g} / \mathrm{head} /$ day of each supplement added into the morning concentrate diet. The ratio of concentrate to roughage was about $3: 1$. Fresh water was available twice daily and mineral blocks were freely available. Routinely, animals were injected once by vitamin A and D (1 $\mathrm{ml} / \mathrm{Kg}$ body weight) throughout the experiment. Feed intake and live body weight were recorded biweekly. More yeast culture contains 148 million cfu of Saccharomyces cervisiae per gram of media consisting of yellow corn, corn gluten, wheat bran, barley, corn flax and molasses. CenMose contains 11.6 x 106 cfu per gram of Saccharomyces cervisiae (min. 1,000 billion cfu), Bacillus subtilis fermentation product (min. 5 million cfu), $\beta 1,3$ - $\beta 1$, 6D-glucan, manna based oligosaccharide, celluolase, protease, amylase, and minerals and vitamins mix . Both of growth stimulants are produced in USA. Total viable cell counts on the culture were reported by the manufacturer and also estimated by the investigators using the standard method of Collins and Particia (1976). Growth stimulant samples were chemically analyzed according to A.O.A.C. (2000). All ration ingredients and growth stimulant chemical composition is presented in Table 1 . The concentrate feed mixture (CFM) is composed of $25 \%$ yellow corn, $28 \%$ uncorticated cottonseed meal, $37 \%$ wheat bran, $7 \%$ molasses, $2 \%$ limestone and $1 \%$ common salt. 


\section{Digestibility trial}

By the end of the experimental period, rectal grab samples were withdrawn from five animals of each group to determine nutrient digestibility and nutritive value using Acid Insoluble Ash ( AIA ) technique (Van Keulen and Young, 1977). Feces samples were collected twice a day for four successive days from each animal for chemical analysis according to A. O. A. C. (2000).

\section{Slaughtering measures}

Three animals out of seven were slaughtered by the end of the digestion trial. Immediately after dressing, the internal (liver, spleen, heart, lungs with trachea and kidneys) and the external (head, hide, four legs, full and empty rumen, intestine and tail) offals were weighed. Then hot carcass weight was recorded to calculate dressing percentage. All carcasses were split longitudinally into right and left sides and weighed. The right side from each carcass was divided into fore and hind quarters between the 8th and 9th ribs. Fore quarter was dissected into fore shank, neck, shoulder, fore ribs, flat ribs and brisket, while hind quarter was dissected into hind shin, flank, sirloin, fillet and best ribs. The whole joints were weighed. Each of these cuts was dissected into meat and bone then recorded (Khalil and Eid, 2004). Percentage of boneless meat was calculated as a percentage of carcass weight. Best ribs $\left(9,10\right.$ and $11^{\text {th }}$ ribs) cut was chilled at $4{ }^{\circ} \mathrm{C}$ for 24 hours. Then eye muscle (Longissimus dorsi) area $\left(\mathrm{cm}^{2}\right)$ was measured at $10^{\text {th }}$ rib muscle before deboning of chilled muscle, using LI-COR Area Meters.

\section{Meat quality}

After chilling, the expressible fluid was measured, expressed in weight according to Grau and Hamm (1956). The Longismus dorsi muscles were trimmed until free of covering fat, then excised and stored at $-24^{\circ} \mathrm{C}$ for about 2 months for cooking loss determination. All chemical analysis procedures were carried out accordance to A.O.A.C. (2000).

\section{Economical feasibility}

Economic efficiency expressed as the ratio between price of total live weight gain and the price of total feed consumed has been calculated as (total weight gain price / total feeding cost). Also, profitability percentage as net surplus over total feeding cost has been calculated to check if the supplementation is economically feasible or not.

\section{Statistical analysis}

Data pooled were statistically analyzed for one way analysis using MSTATC (Nissen, 1989). Means are separated and significance was defined at $\mathrm{p}<0.05$ using Duncan's Multiple Range Test.

\section{RESULTS AND DISCUSSION}

\section{Diet ingredients composition}

The chemical composition of the diet ingredients is presented in Table 1. The chemical composition of growth stimulants indicated More yeast is higher in crude protein, ether extract and nitrogen free extract, while, less in crude fiber and ash content comparing with CenMose. 
Table 1. Chemical composition (\% DM basis) of diet ingredients and growth stimulant supplements

\begin{tabular}{lllllllll}
\hline Ingredient & \multicolumn{7}{c}{ Composition, \% } \\
\cline { 2 - 9 } & DM & OM & CP & EE & CF & Ash & NFE & AIA * \\
\hline CFM & 91.56 & 92.55 & 17.61 & 3.78 & 14.65 & 7.45 & 56.51 & 1.54 \\
Clover hay & 91.06 & 85.65 & 14.09 & 1.59 & 30.41 & 14.35 & 39.56 & 0.72 \\
Rice straw & 92.68 & 84.55 & 4.90 & 1.10 & 33.83 & 15.45 & 44.72 & 10.99 \\
More yeast & 89.37 & 94.43 & 30.64 & 4.60 & 5.50 & 5.57 & 53.69 & -- \\
CenMose & 94.17 & 89.74 & 27.67 & 2.45 & 15.20 & 10.26 & 44.42 & --- \\
\hline
\end{tabular}

* Acid Insoluble Ash

\section{Body weight change, feed intake and feed conversion}

Live weight change, daily gain, feed intake and feed conversion are presented in Table 2. Although, growth stimulant supplementation has no significant effect either on final body weight or average daily gain, average daily gain increased by $21 \%$ as a result of using CenMose. These findings may be attributed to the high feeding value expressed as total digestible nutrients (TDN), starch value (SV) and digestible crude protein (DCP) presented in Table 3. Results obtained on live weight gain are confirmed by the findings of Ali (2005) in sheep and Khalil (2000) in buffalo, however, other investigators concluded that yeast supplementation have no significant effect on live weight gain (Adams, et al., 1981; Quigley, et al., 1992 and Mutsvangwa et al., 1992). Failla et al. (1997) reported that ration of high energy density could improve growth rate of buffaloes. With natural additives, Kang et al. (1992) noted that adding $0.25 \%$ Scaccharomyces cervisae, 0.1\% Clostridium butricum, and $0.15 \%$ Lactobacillus acidophilus increased the daily gain in Holstein bulls.

Table 2. Body weight change, feed intake, and feed conversion of culled female buffalo fed diets supplemented with growth stimulants

\begin{tabular}{lllll}
\hline Item & Control & More yeast & CenMose & \pm SE \\
\hline Body weight change, Kg & & & & \\
Initial live body weight & 429 & 431 & 445 & 50.74 \\
$\begin{array}{l}\text { Final live body weight } \\
\text { Total live weight gain }\end{array}$ & 510 & 508 & 550 & 49.83 \\
$\begin{array}{l}\text { Average daily gain } \\
\text { Feed intake, Kg/h/d }\end{array}$ & 0.986 & 1.057 & 1.195 & 0.14 \\
$\begin{array}{l}\text { Dry matter } \\
\text { Total digestible nutrients }\end{array}$ & 8.753 & 8.865 & 9.075 & 0.63 \\
$\begin{array}{l}\text { Digestible crude protein, g } \\
\text { Feed conversion }\end{array}$ & 1006 & 6.391 & 6.450 & 0.47 \\
Kg DMI / Kg weight gain & 9.534 & 8.761 & 1054 & 81.16 \\
Kg TDNI / Kg weight gain & 6.856 & 6.330 & 7.737 & 1.28 \\
\hline
\end{tabular}

Means within the raw having different scripts are significantly different at $\mathrm{P}<0.05$

Feed intake was adjusted according to live body weight and daily gain, so that feed intake was not significantly different among the different treatments (Table 2). Feed conversion was improved with both supplements vs. the control. Female 
buffaloes fed on CenMose supplemented diet were more efficient in feed conversion than those fed on More yeast supplemented diet (Table 2). The present results are more promising than those reported by Fayed (1995), where, feed efficiency values expressed as Kg DM, SV and g DCP / Kg gain of male buffalo calves were 12.98, $14.03 \mathrm{Kg} \mathrm{DM}, 5.88,6.33 \mathrm{Kg} \mathrm{SE}$ and 1580, $1660 \mathrm{~g} \mathrm{DCP}$ fed on Lacto sac supplemented and control group, respectively. It seems that subjecting the culled female buffalo to intensive finishing regimen, stimulates body response to gain weight in a favorable way, specially after a long time of body weight stability or loss as lactating animal.

\section{Nutrients digestibility and feeding value}

Although, More yeast and CenMose supplementation had no significant effect on nutrients digestibility, total digestible nutrients and digestible crude protein, CenMose supplementation showed the highest values almost for all nutrients digestibility coefficients and nutritive value (Table 3). Results indicate the improvement impact of CenMose as growth stimulant on rumen micro flora and consequently improved digestion pattern. That may interpret the average daily gain improvement that occurred with CenMose supplementation as shown in Table 2. Similar findings were reported by Allam et al. (1999) who indicated that the natural additives stimulated rumen microflora activity through one or more of the following; 1) Decreasing number and activity of antagonistic organisms; 2) Saving some improvement micro factors to rumen microorganisms such as micro elements, vitamins, polysaccharides and enzymes or unknown factors required to the efficient digestion, absorption and metabolism; 3) Decreasing hazards of mycotoxins by inhibition of fungi growth and aflatoxin production. Similarly, results obtained by Gomez et al. (1990) and Wohlt et al. (1991) indicated that addition of Aspergillus oryza and Saccharomces cerivesiae in ruminants diet had different responses according to the diet nature. Also, these results were confirmed by Chademana and Offer (1990), Mir and Mir (1994) and Olson et al. (1994). In contrast, others indicated very slight decrease and inconsistent results particularly for dry matter or protein digestibility in response to live yeast culture supplementation (Adams, et al., 1981; Williams et al., 1991) and Chiquette, 1995). Kang et al. (1992) reported that dry matter, crude protein and crude fiber digestibility was improved in buffaloe heifers fed on diets supplemented with yeast and/or bacteria. Khinizi (1999) used natural additives as growth promoters to study their effect on feed utilization and efficiency and reported that animals fed on Basporo additives at the level of $10 \mathrm{~g} / \mathrm{h} / \mathrm{d}$ showed better feeding value and feed efficiency expressed as TDN more than those fed on $10 \mathrm{~g} / \mathrm{h} / \mathrm{d}$ of natural additives and untreated once. 
Table 3. Nutrients digestibility and feeding value of diets supplemented with growth stimulants

\begin{tabular}{lllll}
\hline Item & Control & More yeast & CenMose & \pm SE \\
\hline Nutrients digestibility, \% & & & & \\
DM & 73.0 & 71.64 & 76.30 & 1.65 \\
OM & 75.87 & 74.91 & 79.04 & 1.63 \\
CP & 75.30 & 73.86 & 78.61 & 2.17 \\
EE & 89.9 & 85.25 & 92.31 & 3.40 \\
CF & 60.31 & 63.04 & 62.16 & 2.94 \\
NFE & 80.75 & 78.84 & 84.22 & 1.71 \\
Feeding value,\% & & & & \\
Total digestible nutrients & 72.01 & 71.89 & 75.00 & 1.60 \\
Starch value & 59.86 & 57.17 & 60.01 & 1.40 \\
Digestible crude protein & 11.49 & 11.15 & 11.58 & 0.26 \\
\hline Means within the raw having different scripts are significantly different at $\mathrm{P}<0.05$
\end{tabular}

\section{Carcass traits}

\section{Carcass characteristics}

Carcass value is considered as an extraordinary term which depends on a wide range of factors concerned with some qualitative and quantitative traits. As indicated in Table (4), CenMose growth stimulant improved carcass traits. Although dressing \%, boneless meat $\%$, fat thickness and eye muscle area were non-significantly different among groups. CenMose supplemented diet recorded the highest percentages of dressing $(55.22 \%)$, boneless meat $(44.44 \%)$ and meat / bone ratio (4.06) compared to More yeast (52.73, 40.77 and 3.44, resp.) and control ones (53.23, 42.35 and 3.83, resp.). These results could be attributed to the composition of CenMose which was reflected in better carcass traits. Control and More yeast supplemented diets were very comparable in dressing \% and boneless \%, in comparison. Values of the eye muscle area seem to be lower than others (Houria and Omar, 1994; Fiem, et al., 1995 and Khalil, 2000) in both culled females buffaloes and cattle. It might be due to using the LI-COR Area Meters, which gives more precise results than the ordinary plannemeter (Khalil and Eid, 2004).

Table 4. Carcass characteristics of culled female buffalo fed diets supplemented with growth stimulants

\begin{tabular}{|c|c|c|c|c|}
\hline Trait & Control & More yeast & CenMose & \pm SE \\
\hline \multicolumn{5}{|c|}{ Carcass characteristics: } \\
\hline $\begin{array}{l}\text { Slaughter weight, } \\
\mathrm{Kg}\end{array}$ & 496 & 472 & 519 & 32.70 \\
\hline Dressing, $\%$ & 53.23 & 52.73 & 55.22 & 1.41 \\
\hline Boneless meat, \% & 42.35 & 40.77 & 44.44 & 1.13 \\
\hline Meat / Bone & 3.83 & 3.44 & 4.06 & 0.27 \\
\hline L. Dorsi area, $\mathrm{cm} 2$ & 35.71 & 33.01 & 33.11 & 2.85 \\
\hline Fat thickness, mm & 13.00 & 17.33 & 15.67 & 3.54 \\
\hline
\end{tabular}

Means within the raw having different superscripts are significantly different at $\mathrm{P}<0.05$ 


\section{Carcass cuts}

Carcass cuts indicated that left forequarter, neck; total and meat, fore shank; total, shoulder; total and meat, best ribs; total and fat were significantly higher for CenMose supplemented diet than the control or More yeast diets (Table 5). No differences were found for the other carcass cuts among growth stimulants supplemented diets and the control diet. In general, carcasses can be classified into major cut groups upon their quality into best (round, sirloin, fore ribs, best ribs and fillet), medium (shoulder, brisket, flat ribs and neck) and inferior cuts(flank, for shank and hind shank) according to Weinger et al. (1963) as presented in Table 6. CenMose growth stimulant slightly enhanced the quantity of meat. Similar results were found in finished culled female buffalo fed on natural additives supplemented diets (Khalil, 2000).

\section{External and internal offals}

External, internal offals and some organs fat, expressed as percentage of slaughter weight are presented in Table 7. No changes were found concerning the external and internal offals percentages in response to feed culled female buffalos on growth stimulants supplemented diets. Considering the initial and final body weight, the full rumen percentage was proportionally higher for animals feed on CenMose supplemented diet (Tables 2 and 7).

\section{Meat quality}

Supplementation of More yeast and CenMose as growth stimulant to culled female buffalo diets non-significantly changed the chemical composition of L. Dorsi muscle (Table 8 ). However, animals fed on More yeast supplemented diet scored the lowest percentage of expressible fluid (24. $70 \%$ ) and cooking loss $(35.03 \%)$ with the highest fat thickness $(17.33 \mathrm{~mm})$ compared to other groups. This result could be due to that cooking loss was diminished by enhancing water holding capacity (Lawrie, 1974). In addition, the expressible fluid may be defined as a result of compact firmness of muscle in this group. Also, animals fed on More yeast supplemented diet recorded highest percentage of intramuscular fat (ether extract) with lowest percentage of protein content in comparison with the other groups. Higher water content would coincide with higher protein content, based on the close relationship between nitrogen deposition and water retention (Fiems et al., 1995). Both ether extract and fat thickness results are positively responsive to growth stimulant supplementation in more yeast group (Tables 4 and 8). In addition, non-significant high increase in ether extract and ash as well was observed with the More yeast diet rather than the other diets. However inverse relationship between moisture and fat content of the L. Dorsi was reported by Afifi et al. (1977) and Salem et al. (1982). There was no obvious trend or correlation between fat and moisture in the present investigation. 
Table 5. Carcass cuts, \% of carcass weight for culled female buffalo fed diets supplemented with growth stimulants

\begin{tabular}{|c|c|c|c|c|}
\hline Cuts & Control & More yeast & CenMose & \pm SD \\
\hline Slaughter weight, Kg & 496 & 472 & 519 & 23.50 \\
\hline Carcass weight, $\mathrm{Kg}$ & 263 & 248 & 286 & 19.14 \\
\hline Neck; Total & 6.40 & 5.73 & 6.17 & 0.34 \\
\hline Meat & 5.20 & 4.43 & 5.14 & 0.43 \\
\hline Bone & 1.20 & 1.31 & 1.06 & 0.12 \\
\hline Fore shin; Total & 3.44 & 3.49 & 3.34 & 0.08 \\
\hline Meat & 2.02 & 1.92 & 1.95 & 0.05 \\
\hline Bone & 1.42 & 1.58 & 1.39 & 0.10 \\
\hline Shoulder; Total & 14.02 & 12.71 & 13.82 & 0.71 \\
\hline Meat & 11.77 & 10.37 & 11.62 & 0.77 \\
\hline Bone & 2.24 & 2.34 & 2.21 & 0.07 \\
\hline Foreribs; Total & 9.64 & 9.99 & 9.39 & 0.30 \\
\hline Meat & 6.83 & 5.76 & 7.01 & 0.67 \\
\hline Bone & 2.81 & 4.23 & 2.37 & 0.97 \\
\hline Flat ribs; Total & 5.56 & 6.56 & 6.15 & 0.50 \\
\hline Meat & 4.37 & 5.27 & 4.98 & 0.46 \\
\hline Bone & 1.20 & 1.28 & 1.17 & 0.06 \\
\hline Brisket; Total & 6.47 & 6.39 & 6.20 & 0.14 \\
\hline Meat & 5.33 & 5.03 & 5.07 & 0.16 \\
\hline Bone & 1.14 & 1.36 & 1.13 & 0.13 \\
\hline Hind shank; Total & 3.85 & 4.35 & 3.98 & 0.26 \\
\hline Meat & 1.71 & 2.22 & 1.93 & 0.26 \\
\hline Bone & 2.13 & 2.17 & 2.05 & 0.06 \\
\hline Flank; Total & 8.65 & 9.98 & 10.03 & 0.78 \\
\hline Meat & 7.55 & 8.72 & 9.00 & 0.77 \\
\hline Bone & 1.10 & 1.26 & 1.02 & 0.12 \\
\hline Round; Total & 31.09 & 30.03 & 29.96 & 0.63 \\
\hline Meat & 26.76 & 25.65 & 25.37 & 0.74 \\
\hline Bone & 4.33 & 4.37 & 4.59 & 0.14 \\
\hline Sirloin; Total & 5.53 & 5.57 & 5.52 & 0.03 \\
\hline Meat & 3.40 & 3.40 & 3.66 & 0.15 \\
\hline Bone & 2.13 & 2.18 & 1.85 & 0.18 \\
\hline Fillet & 2.58 & 2.70 & 2.46 & 0.12 \\
\hline Best ribs; Total & 2.74 & 2.49 & 2.97 & 0.24 \\
\hline Meat & 1.34 & 1.21 & 1.35 & 0.08 \\
\hline Fat & 0.63 & 0.50 & 0.86 & 0.18 \\
\hline Bone & 2.51 & 0.77 & 0.75 & 1.01 \\
\hline
\end{tabular}


Table 6. Best, medium and inferior quality cuts, \% of carcass weight for culled female buffalo fed diets supplemented with growth stimulants

\begin{tabular}{lllll}
\hline Item & Control & More yeast & CenMose & \pm SD \\
\hline Carcass & weight, & & & \\
Kg & 263 & 248 & 286 & 19.14 \\
$\begin{array}{l}\text { Best* } \\
\quad \text { Whole }\end{array}$ & 51.59 & 50.78 & 50.30 & 0.65 \\
$\quad$ Meat & 41.54 & 39.22 & 40.52 & 1.16 \\
$\quad$ Bone & 11.79 & 11.55 & 9.57 & 1.22 \\
Medium** & & & & \\
$\quad$ Whole & 32.45 & 31.39 & 32.34 & 0.59 \\
$\quad$ Meat & 26.67 & 25.10 & 26.81 & 0.95 \\
$\quad$ Bone & 5.78 & 6.29 & 5.57 & 0.37 \\
Inferior*** & & & & \\
$\quad$ Whole & 15.93 & 17.82 & 17.34 & 0.98 \\
$\quad$ Meat & 11.28 & 12.87 & 12.88 & 0.92 \\
$\quad$ Bone & 4.65 & 5.00 & 4.45 & 0.28 \\
\hline
\end{tabular}

* Best quality cuts (round, sirloin, fore ribs, best ribs and fillet).

** Medium quality cuts (shoulder, brisket, flat ribs and neck).

*** Inferior quality cuts (flank, fore shin, and hind shank).

Table 7. External, internal offals and fat distribution, \% of slaughter weight for culled female buffalo fed diets supplemented with growth stimulants

\begin{tabular}{lllll}
\hline \multicolumn{1}{c}{ Item } & Control & More yeast & CenMose & 土SD \\
\hline $\begin{array}{l}\text { Slaughter weight } \\
\text { External offals: }\end{array}$ & 496 & 472 & 519 & 23.50 \\
$\quad$ & & & & \\
Head & 5.04 & 5.37 & 5.14 & 0.17 \\
Hide & 7.59 & 8.47 & 8.73 & 0.60 \\
Tail & 0.38 & 0.35 & 0.31 & 0.03 \\
Legs & 2.47 & 2.59 & 2.43 & 0.08 \\
Internal offals: & & & & \\
Full rumen & 11.29 & 11.23 & 12.52 & 0.73 \\
Empty rumen & 4.10 & 4.36 & 4.25 & 0.13 \\
Full intestine & 5.24 & 5.65 & 3.98 & 0.87 \\
Empty intestine & 3.53 & 3.88 & 3.28 & 0.31 \\
Liver & 1.08 & 1.21 & 1.05 & 0.08 \\
Spleen & 0.21 & 0.23 & 0.24 & 0.01 \\
Heart & 0.45 & 0.44 & 0.48 & 0.02 \\
Kidneys & 0.30 & 0.40 & 0.33 & 0.05 \\
Lung & 1.67 & 1.93 & 1.84 & 0.13 \\
Fat: & & & & \\
Heart fat & 0.12 & 0.15 & 0.25 & 0.07 \\
Kidneys fat & 0.73 & 0.54 & 1.25 & 0.37 \\
Caul fat & 0.54 & 0.70 & 0.67 & 0.09 \\
Intestine fat & 0.38 & 0.28 & 0.55 & 0.14 \\
\hline Table 8.
\end{tabular}

Table 8. $L$. Dorsi meat quality of culled female buffalo fed diets supplemented with growth stimulants 


\begin{tabular}{lllll}
\hline Trait & Control & More yeast & CenMose & \pm SE \\
\hline $\begin{array}{l}\text { Meat quality: } \\
\text { Physical: }\end{array}$ & & & & \\
$\quad$ WHC,\% & 31.47 & 24.70 & 34.47 & 3.58 \\
$\quad$ Cooking loss, $\%$ & 40.43 & 35.03 & 40.37 & 1.52 \\
Chemical: & & & & \\
$\quad$ Dry matter & 27.05 & 27.41 & 28.33 & 1.43 \\
$\quad$ Crude protein & 22.59 & 21.62 & 22.36 & 1.11 \\
$\quad$ Ether extract & 2.97 & 4.50 & 2.59 & 0.72 \\
$\quad$ Ash & 0.857 & 1.130 & 0.997 & 0.13 \\
$\quad$ Moisture & 72.95 & 72.59 & 71.67 & 1.43 \\
\hline
\end{tabular}

Means within the raw having different superscripts are significantly different at $\mathrm{P}<0.05$

\section{Economic evaluation}

In terms of money, the economic efficiency has been calculated using the current market price of feed ingredients and growth stimulants supplementation (LE/Ton), 1100 for CFM, 650 clover hay, 100 for rice straw, 15 for $1 \mathrm{Kg}$ More yeast, 25 for $1 \mathrm{Kg}$ CenMose and LE 12 for $1 \mathrm{Kg}$ of live body weight. Economic evaluation data (Table 9) indicated that although concentrate mixture feeding and daily feeding cost of the animals fed on CenMose supplemented diet was relatively higher than the other groups, feeding cost / Kg gain was lower and economically more efficient. Profitability was calculated over total feeding cost and indicated that $10 \%$ more has been achieved as a result of CenMose supplementation compared to the control diet.

Table 9. Economic evaluation of growth stimulants supplementation to culled female buffalo diets

\begin{tabular}{|c|c|c|c|c|}
\hline Item & Control & More yeast & CenMose & $\pm \mathrm{SE}$ \\
\hline \multicolumn{5}{|l|}{ Price of feed intake, LE/h/d } \\
\hline CFM & $7.85^{\mathrm{ab}}$ & $6.85^{b}$ & $8.77^{\mathrm{a}}$ & ----- \\
\hline Clover hay & 0.65 & 0.65 & 0.65 & ----- \\
\hline Rice straw & 0.135 & 0.130 & 0.140 & ----- \\
\hline Growth stimulant & 0.00 & 0.15 & 0.25 & ----- \\
\hline Feeding cost, LE/h/d & 8.64 & 9.20 & 9.66 & 0.53 \\
\hline Feeding cost, LE/Kg gain & 9.29 & 9.08 & 8.30 & 0.85 \\
\hline Economic efficiency & 1.38 & 1.42 & 1.47 & 0.14 \\
\hline Profitability, $\%$ / feeding cost & 37.7 & 41.7 & 46.9 & 13.3 \\
\hline
\end{tabular}

\section{CONCLUSION}

In conclusion, culled female buffaloes could be exploited as a good source of meat by improving body weight gain potential through natural growth stimulant supplements. Adding CenMose (mixture of polysaccharides, bacteria, enzymes, vitamins and mineral) at $10 \mathrm{~g} /$ head / daily improved digestion pattern, body gain performance and carcass traits as well. In addition, More yeast growth stimulant 
could be used to improve meat quality. Through using growth stimulants, culled female buffaloes have a promising potential to improve growth rate and carcass characteristics after being fed for long time as lactating animal.

\section{AKNOWLEDGMENT}

The authors would like to thank Dr. Enaam M.M., Professor, Department of Buffalo Breeding Reseach, Animal Production Institute, for her helpful guidance and fruitful discussions.

\section{REFERENCES}

Adams, D.C., M.L. Galyean, and H.E. Kiesling, 1981. Influnce of viable yeast culture, sodium bicarbonate and monensin on liquid dilution rate, rumen fermentation and feedlot performance of growing steers and digestibility in lambs. J. Anim. Sci., 53: 780-789.

Afifi, Y.A., H.A. El-Koussy, S.S. El-Khishen and M.A. El-Ashry, 1977. Production of meat from Egyptian buffaloes. II. The effect of using different sources of roughages on carcass traits. Egypt. J. Anim. Prod., 17: 165-171.

Allam, S.M., Hoda, M. El-Hosseiny, A.M. Abdel-Gawad, S.A. El-Saadany and A.M.M., Zeid, 1999. Medicinal herbs and plants as feed additives for ruminants. 1. Effect of using some medicinal herbs and plant as feed additives on Zaraibi goat performance. Egypt. J. Nutrition and Feeds, 2 (special issue): 349.

A.O.A.C., 2000. Official Methods of Analysis (10 ${ }^{\text {th }}$ Ed.). Assoc. Of Official Chemists.

Chademana, I and N.W. Offer, 1990. The effect of dietary inclusion of yeast culture on digestion in the sheep. J. Anim. Prod., 50:48, 489.

Chiquette, J., 1995. Saccharomyces cervisiae and Aspergillus oryzae, used alone or in combination, as a feed supplement for beef and dairy cattle. Can. J. Anim. Sci. 75: 405-415.

Collin, C.H. and M.H.Patricia, 1976. Microbiological Methods. "Fourth Edition". Billing and Sons LTD, London and Grldford.

Edwards, I.E., 1991. Practical uses of yeast in culture in beef production: Insight into its mode of action. In: Biotechnology in the Feeds Industry, Vol. VI. Alltech Technical Publications, Nicholasville, KY.

Eid, Laila N., S. A. Darwish, Safaa S. A. Khalil and Enaam M. Mokhless, 2003. A comparative study of the anatomy of the reproductive tract in repeat-breeder heifers and adult buffaloes. Buffalo J. Vol. 19 (3): 261-271.

Failla, S.; Iacurto, M.Gigli, S. And Bisegna, V., 1997. Meat quality charactreristics of buffaloes, slaghutered at two different ages in comparison with typical Italian beef genotypes. The $5^{\text {th }}$ World Buffalo Congress Proceedings, Royal Palace Caserta, Italy, October 13-16.

Fallon, R.J. and F.J. Harte, 1987. The effects of yeast culture inclusion in the concentrate diet on calf performance. J. Dairy Sci. 70 (Suppl. 1):143.

Fayed, A.M.M., 1995. factors affecting productive performance of buffalo male calves till slaughter. Ph.D. Thesis, fac. Of Agric., Ain Shams Univ., Cairo.

Fiems, L.O., C.V. Bouque, D;L. Brabander and B.G. Cottyn, 1995. The effect of the $\beta$-adrenergic agonist cimaterol on performance and carcass and meat quality in culled dairy cows. J. Anim. Sci., 61: 19-23. 
Gomez-Alarcon, R.A., C.Dudas, and J.T. Huber, 1990. Influence of cultures of Aspergillus oryzae on rumen and total tract digestibility of dietary components. J. Dairy Sci. 73:703-710.

Grau, R. and R. Hamm, 1956. Die Bestimmung des Wasserbindung des Fleiches mittels der Pressmethode. Die Fleischwirtschaft, 36: 733 (Cited in Fiems et al., 1995).

Houria, M. A. and S.S. Omar, 1994. Evaluation of meat production from culled female buffaloes. Egypt. J. Anim. Prod., 31: 1-14.

Hughes, J., 1988. Effect of high strength yeast culture in diets of early weaned calves. Anim. Prod. 46:526.

Kang, W.S., S.C. Lee, S.K. Yoon, E.S. Chung and K.J. Lee, 1992. Effect of live yeast culture on growth performance and beef productivity of Holstein bulls. Korean J. Anim. Sci., 34: 108-115. (Abst).

Khalil, Safaa S. A., 2000. Effect of some natural additives on meat production from buffaloes. Ph. D. Thesis, Fac. of Agric., Cairo Univ.

Khalil, Safaa S. A. and Eid, N. Laila, 2004. Culled buffalo heifers as a potential source for beef production. J. Agric. Sci. Mansoura Univ., 29 (9): 4903-4916.

Khinizy, A.F.M., 1999. Effect of using some growth promoters on rations digestibility and lamb performance. Egypt. J. Appl. Sci., 14: 1-6.

Lawrie, R.A., 1974. Meat Science. Text Book, $2^{\text {nd }}$ edition, Pergamon Press, Oxford, New York. Toronto Sydney, Braunsch-Weig.

MALR, 1995. Ministry of Agriculture and Land Reclamation, Egypt.

McLeod, K.R., K.J. Karr, K.A. Dawson, R.E. Tucker and G.E. Mitchell, Jr. 1990. Rumen fermentation and nitrogen flow in lambs receiving yeast culture and (or) meonensin. J. Dairy Sci. 73 (Suppl. 1):266.

Mir, Z. and P.S. Mir, 1994. Effect of the addition of live yeast (Saccharomyces cervisiae) on growth and carcass quality of steers fed high-forage or high-grain diets and on feed digestibility and in situ degradability. J. Anim. Sci., 72:537545.

Mutsvanwa, T., I.E. Edwards, J.H. Topps, and G.F.M. Paterson, 1992. The effect of dietary inclusion of yeast culture (Yea-Sacc) on patterns of rumen fermentation, food intake and growth of intensively fed bulls. Anim. Prod., 55: $35-40$.

Nissen, O., 1989. MSTAT4. Michigan State Univ. Statistical package. Dept. of Crop and Soil Science, Michigan State Univ., E. Lansing, Michigan 48824. USA.

Olson, K.C., J.S. Caron, D.R. Kirby, and P.L. Nortorn, 1994. Influence of yeast culture supplementation and advancing season on steers grazing mixed-grass prairie in the Northern great plains: 1. Dietary composition, intake, and in situ nutrient disappearance. J. Anim. Sci., 72: 2149-2157.

Quigley, J.D., L.B. Wallis, H.H. Dowlen, and R.N. Heitmann, 1992. Sodium bicarbonate and yeast cultureeffects on ruminal fermentation, growth, and intake in dairy calves. J. Dairy Dci. 75: 3531-3538.

Ranjhan, S. K., 1999. Animal nutrition and feeding practices. Sixth Revised Edition, VIKAS Pub. House PVT LTD.

Salem, M.A.I., A. Darwish, G.A. Abd El-Hafez and M. Nasrat, 1982. Growth and meat quality of nutrition. II. The quality of lean. Egypt. . Anim. Prod., 22: 83. 
Van Kulen, j. AND Young, B.A., 1977. Evaluation of acid-insoulbele ash as a natural marker in ruminant digestibility studies. J. Anim. Sci., 44:282. Washington, DC.

Weinger, J.H., Steinhauf, D. and Phl, G.H.M., 1963. Muskeltopographie der Schlachtkorper. Muscular Topography of Carcasses. Text Book. BLV verlagsgesellschaft Munchen Basel Wien, Germany.

Williams, P.E.V., 1988. Understanding the biochemical mode of action of yeast culture. In Biotechnology in the feed industry (ed. T.P. Lyons), pp. 79-99. Alltech technical Publications, Nicholasville, Kentuaky.

Williams, P.E.V., C.A.G. Tait, G.M. Innes and C.J. Newbold, 1991. Effects of of the inclusion of yeast culture (Saccharomyces cervisiae plus growth medium) in the diet of dairy cows on milk yield and forage degradations and fermentation patterns in the rumen of steers. J.Anim. Sci., 69: 3016-3026.

Wohlt, J.E., A.D. Finkelestein, and C.H. Chung, 1991. Yeast culture to improve intake, nutrient digestibility, and performance by dairy cattle during early lactation. J. Dairy Sci., 74: 1395-1400. 


\title{
تأثير إضافة منشطات النمو الطبيعية إلى العلائق على الأداء الإنتاجي وصفات الذبيحة والجدوى الإقتصادية لإناث الجاموس المستبعدة
}

\author{
صفاء شعبان أحمد خليل' - محمد حسن عبدالجواد'

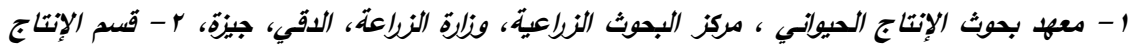

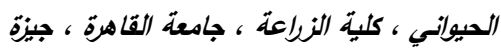

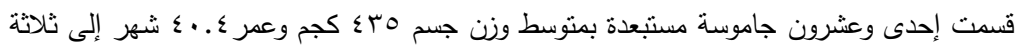

مجموعات متساوية ـ هدفت هذه الدراسة إلى قياس درجة استجابة إناث الجاموس المستبحدة لعليقتين مضاف

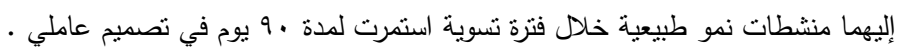

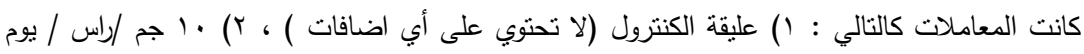

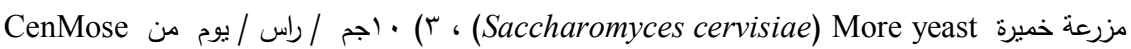
(مخلوط سكريات عديدة وبكتريا نافعة وأحماض أمنية وإنزيمات هاضمة وفيتامينات و وعناصر صنرى وكبرى).

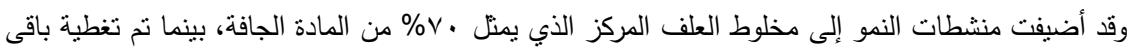

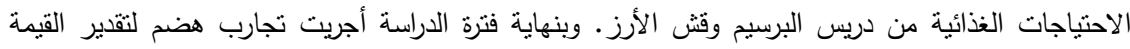

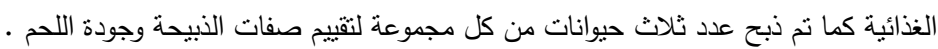

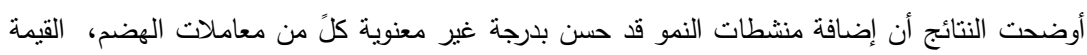

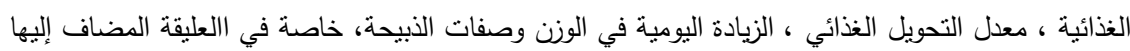
CenMose

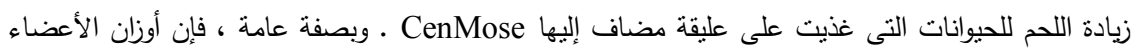

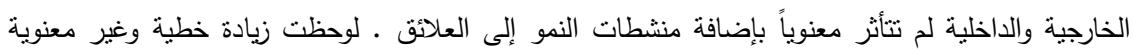

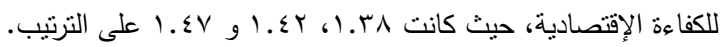
وقد استتتج من هذه الدراسة أن إضافة منشطات النمو لعليقة النسوية لإناث الجاموس المستبعدة قد حسن

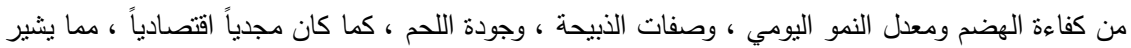
إلى إمكانية تحقيق معدلات نمو مرضية للإناث المستبعدة . 